\title{
Prosedur Penyebaran Risiko Asuransi kebakaran dalam Reasuransi Treaty Proporsional; Study kasus PT. Tugu Pratama Indonesia.
}

Kuncoro ${ }^{1}$

${ }^{1}$ Laboratorium Asuransi dan Aktuaria, Program Vokasi UI, kuncorohp@gmail.com

Diterima : 1 Februari 2014

Layak Terbit : 18 Juli 2014

\begin{abstract}
Abstrak
Banyak orang menyadari pentingnya mengenal produk asuransi secara professional guna meraih penghasilan investasi setinggi mungkin, namun keinginan untuk mendapatkan penghasilan yang besar diikuti juga dengan berbagai pertimbangan. Umumnya setiap orang menginvestasikan uangnya dengan tujuan ingin meningkatkan standar kehidupan yang lebih baik, untuk memberikan santunan mereka yang menjadi tanggungjawabnya, mendapatkan proteksi atas situasi keuangan rumah tangganya, mempersiapkan memasuki masa pensiun, atau menyediakan untuk kebutuhan pendidikan keluarga pada saat orang tersebut meninggal dan masih banyak lagi pilihan tergantung dari tujuan
\end{abstract}

Kata Kunci : Produk asuransi, investasi, proteksi keuangan

\section{Abstract}

Understanding the principles of insurance professionally are an important things for those insurer, in return for the payment of a premium, promises to pay an amount of money on the occurrence of a defined events. By doing so this enables an individual to protect themselves against the financial effects of certain event or events.

Keywords: Insurance product, investment, finance protection

\section{PENDAHULUAN}

\section{Latar Belakang}

Asuransi merupakan metode yang paling praktis untuk menangani risiko keuangan, sehingga asuransi banyak digunakan untuk mengurangi risiko kerugian baik pada individu atau resiko terhadap kepemilikan atas aset yang tangible atau intangible serta kerugian atas keberlangsungan suatu korporasi.

Namun tidak semua jenis risiko dapat diasuransikan karena ada syarat dan ketentuan yang berlaku misalnya salah satu jenis risiko yang dapat diasuransikan haruslah merupakan kumpulan dari beberapa jenis risiko yang sama (The law of Large Number) sehingga obyek dapat dikelola oleh perusahaan asuransi.

Setiap korporasi memiliki risiko terjadinya kerugian. Oleh karena itu, perusahaan asuransi haruslah memiliki dana yang cukup untuk menanggung risiko apabila terjadinya klaim dikemudian hari. Manajeman atau pengelolaan terhadap risiko yang baik sangat diperlukan untuk meminimalisir kerugian yang akan terjadi dalam mengelola risikorisiko yang ada.

Dalam upaya untuk pengelolaan risiko tersebut, korporasi dapat melakukan berbagai alternatif, yaitu dengan cara menanggung 


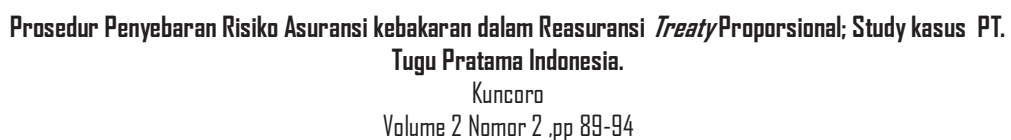

sendiri risiko, mengurangi risiko, memperkecil risiko atau mengalihkan risiko melalui asuransi. Jadi, korporasi tersebut dapat mengalihkan sebagian atau seluruh risiko yang mungkin dihadapi kepada perusahaan asuransi yang lain. Oleh karena itu, perusahaan asuransi memerlukan kebijakan dalam mengelola risiko atas pertanggungan yang diterimanya.

Umumnya pengelolaan resiko pada perusahaan asuransi dikelola dengan cara membagi risiko, yaitu mempertanggungkan kembali risiko yang tidak mungkin mereka tanggung sendiri kepada perusahaan asuransi yang lain sebagai penanggung ulang, yang disebut reasuransi. Dengan demikian reasuransi dapat diartikan sebagai perusahaan asuransi yang menerima pertanggungan ulang dari perusahaan asuransi atas sebagian atau keseluruhan risiko yang telah atau tidak dapat ditanggung kembali oleh perusahaan asuransi. Perusahaan asuransi menerima pemindahan risiko dari perusahaan asuranasi yang menutup secara langsung risiko tertentu dimana nilai pertanggungan tersebut telah melampaui kemampuannya menerima suatu risiko.

\section{Permasalahan}

Dalam sebuah perusahaan asuransi ada divisi reasuransi yang berfungsi untuk mencari dan mendapatkan dukungan reasuransi. Divisi reasuransi merupakan divisi yang penting bagi suatu perusahaan asuransi, karena mengelola kembali risiko yang telah diterima perusahaan.
Dalam pokok permasalahan ini penulis mengambil kasus pada perusahan asuransi terkemuka di Indonesia PT. Tugu Pratama Indonesia dimana perusahaan ini mempunyai divisi reasuransi yang terbagi menjadi 2 subdivisi yakni:

1. Divisi Treaty

2. Divisi Fakultatif

Masing-masing sub-divisi ini terbagi lagi menjadi:

a. Inward, berperan untuk menerima penawaran bisnis dari ceding company,

b. Outward, berperan untuk mencari Reasuradur atau dukungan untuk penutupan suatu bisnis yang didapatkan oleh perusahaan.

Pada divisi treaty yang khususnya bagian outward, perusahaan berperan untuk menentukan penyebaran risiko yang telah ditetapkan sebelumnya dalam perjanjian treaty terhadap suatu bisnis yang dimilikinya. Terdapat 2 bentuk program treaty yakni :

1. Treaty proporsional

2. Treaty non proporsional.

Program reasuransi secara proporsional yakni saham perusahaan reasuransi ditetapkan dalam proporsi atau presentase yang telah ditetapkan baik untuk penerimaan premi maupun pembayaran klaim. Dalam penyebaran risiko terhadap suatu bisnis yang dimiliki oleh perusahaan, dapat menggunakan metode proporsional yang terdiri dari 2 bentuk, yakni Quota Share dan Surplus. Kedua metode tersebut dapat menentukan proporsi risiko yang akan dibagi kepada anggota treaty. 


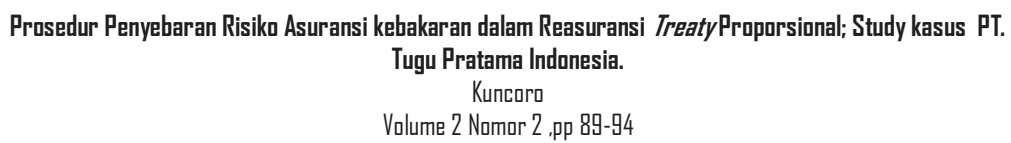

Sedangkan pada treaty non proporsional, seolah-olah perusahaan asuransi membeli asuransi untuk suatu nilai tertentu yang dapat dipakai untuk menutup kerugian yang dideritanya diatas kemampuannya secara akumulatif sampai dengan jumlah tertentu tanpa melihat jumlah risiko yang diatas kemampuannya. Kontrak ini dapat ditetapkan dalah bentuk Excess of Loss Reainsurance Treaty atau Stop Loss Reinsurance Treaty.

\section{Metode Penelitian}

Penulis membahas mengenai "Prosedur Penyebaran Risiko Asuransi kebakaran dalam Reasuransi Treaty Proporsional, study kasus PT. Tugu Pratama Indonesia” penulisan akan dibatasi pada program reasuransi treaty proporsional dengan penggunaan metode surplus dalam bisnis fire di Tugu Pratama Indonesia. Pembahasan difokuskan pada metode surplus, dimana PT. Tugu Pratama Indonesia itu sendiri hanya menggunakan treaty surplus untuk kelas bisnis fire. Hal tersebut dikarenakan dengan menggunakan metode surplus PT. Tugu Pratama Indonesia dapat menentukan sendiri besarnya penyebaran risiko yang akan dilakukan pada suatu bisnis. Tergantung pada baik buruknya risiko bisnis tersebut. Sedangkan pemilihan topik asuransi fire itu sendiri dikarenakan kelas bisnis ini paling banyak diminati dan dikenal oleh masyarakat saat mendengar mengenai asuransi kerugian.

Memberikan gambaran secara umum mengenai prosedur penyebaran risiko dalam treaty reasuransi kepada para pembaca, khususnya para akademis. Implementasi teori reasuransi terhadap praktek yang dilaksanakan oleh PT. Tugu Pratama Indonesia. Menggunakan data sekunder yang telah dilakukan oleh mahasiswa magang Program Vokasi UI.

Tulisan ini akan memberikan gambaran secara umum mengenai prosedur penyebaran risiko dalam treaty reasuransi kepada para pembaca, khususnya para akademis. Akhirnya Implementasi teori reasuransi terhadap praktek yang dilaksanakan oleh PT. Tugu Pratama Indonesia.

\section{HASIL DAN PEMBAHASAN}

Maka dengan menerima empat risiko A sampai dengan D yang berbeda nilai pertanggungan $(S / I)$ nya dengan ketentuan limit lines sesuai contoh di atas, makadistribusi risiko maupun kerugiannya adalah sebagai berikut:

Risiko A :
a. Nilai pertangungan $(S / I) \quad$ Rp. 1 milyar
b. $O / R$ ceding company
Rp. 375 juta
c. First Surplus
Rp. 625 juta
d. Second Surplus
$\mathrm{Rp}-$

Risiko B :
a. Nilai pertangungan (S/I) Rp. 3 milyar
b. $O / R$ ceding company Rp. 400 juta
c. First Surplus Rp. 4 milyar
( $10 \times 400 j t)$
d. Second Surplus
Rp600 juta

Risiko C :
a. Nilai pertangungan $(S / I)$ Rp. 8 milyar
b. $O / R$ ceding company
Rp. 500 juta
c. First Surplus
Rp. 5 milyar
(10 x 500jt)
d. Second Surplus
Rp. 2,5 milyar 
Risiko C :
a. Nilai pertangungan $(S / I)$ Rp. 8 milyar
b. $O / R$ ceding company Rp. 500 juta
c. First Surplus
Rp. 5 milyar
(10 x 500jt)
d. Second Surplus
Rp. $\quad 2,5$ juta
( $5 \times 500 j t)$

Risiko D :
a. Nilai pertanggungan $(S / I)$ Rp. 7 milyar
b. O/R ceding company Rp. 400 juta
c. First Surplus
Rp. 4 milyar
( $10 \times 400 j t)$
d. Second Surplus
Rp. 2 milyar
(5 x 400jt)
e. Facultative
Rp. 600 juta

Bila proporsi surplus tidak mencukupi untuk menanggung besarnya nilai risiko yang ada, maka risiko akan ditempatkan pada reasuransi fakultatif. Namun bila ceding company tidak mendapatkan Reasuradur fakultatif untuk risiko D, maka kelebihan setelah Second Surplus Treaty kembali menjadi tanggungan sendiri ( $O / R$ ceding company).

\section{Quota Share}

Yaitu perjanjian reasuransi dimana pembagian share atas ceding company dengan Reasuradur didasarkan pada prosentase yang telah ditentukan. Ceding company tidak bisa menerima seluruhnya meskipun penutupan itu sama atau lebih kecil dari retensinya. Misalnya suatu reasuransi diadakan atas dasar $60 \%$ quota share, maka dari setiap risiko yang ditutup oleh ceding company tersebut Reasuradur akan menanggung 60\% dari risiko, menerima $60 \%$ premi dan membayar 60\% dari klaim.

Contoh : Ceding company mempunyai bisnis dan menahan 60\% bisnisnya dan 40\% sisanya dibagikan kepada Reasuradur. Komisi reasuransi ditetapkan sebesar 35\%, maka ketika ceding company menerima pertanggungan sebesar Rp. 2 milyar dengan tingkat premi $1 \%$, pelaksanaannya adalah :

Premi awal

$1 \%$ X Rp. 2 milyar $=$ Rp. 20 juta

Saham premi ditahan

60\% X Rp. 20 juta $=$ Rp. 12 juta

Saham premi reasuransi

$40 \%$ X Rp. 20 juta $=$ Rp. 8 juta

Komisi reasuransi

35\% X Rp. 8 juta $=$ Rp. 2,8 juta

Distribusi premi + komisi reasuransi :

a. Ceding company

Rp. 12 juta + Rp. 2,8 juta= Rp. 14,8 juta

b. Reasuradur

Rp. 8 juta - Rp. 2,8 juta=Rp. 5,2 juta

Distribusi risiko :

a. Ceding company

60\% X Rp. 2 milyar=Rp. 1,2 Milyar

b. Reasuradur

40\% X Rp. 2 milyar=Rp. 800 juta

Bila terjadi kebakaran yang mengakibatkan klaim kerugian sebesar Rp. 500 juta, maka proporsi penggantiannya adalah :

Distribusi kerugian :

a. Ceding company

60\% X Rp. 1 milyar=Rp. 600 juta 


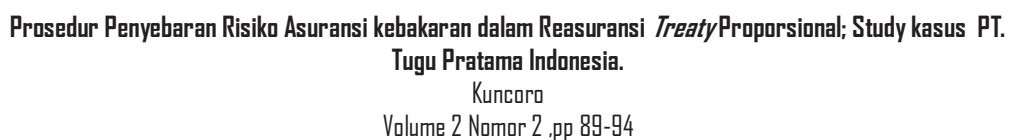

\section{b. Reasuradur}

$40 \%$ X Rp. 1 Milyar $=$ Rp. 400 juta

\section{Facultative Obligatory Reinsurance}

Yaitu perjanjian reasuransi antara ceding company dan Reasuradur dimana ceding company mempunyai kebebasan untuk menggunakan fasilitas reasuransi tersebut atau tidak, sedangkan bagi pihak Reasuradur mempunyai keharusan untuk menerima reasuransi yang dilakukan oleh ceding company.

\section{Non proporsional}

Pertanggungan dimana perusahaan reasuransi menerima risiko sampai dengan nilai tertentu setelah melalui batas kerugian tertentu yang diderita perusahaan asuransi. Jumlah ini merupakan limit tertinggi secara agregatif dalam jangka waktu paling lama 1 tahun underwriting atau bisa kurang apabila jumlah tersebut telah abis dan tidak diperbaharui lagi.

Disini seolah-olah perusahaan asuransi membeli asuransi untuk suatu nilai tertentu yang dapat dipakai untuk menutup kerugian yang dideritanya diatas kemampuannya secara akumulatif sampai dengan jumlah tertentu tanpa melihat jumlah risiko yang di atas kemampuannya. Metode dalam non proporsional ini terdiri dari 2 jenis, yakni Excess of Loss Reinsurance Treaty dan Stop Loss Reinsurance Treaty.

Reasuransi memiliki peran penting dalam keberlangsungan usaha asuransi. Hal ini sesuai dengan salah satu fungsi reasuransi, dengan reasuransi maka perusahaan asuransi dapat memperbesar kapasitas penerimaan risikonya. Dimana kemudian risiko tersebut dapat direasuransikan kembali ke perusahaan reasuransi. Reasuransi memiliki 2 program yakni :

\section{Proporsonal}

2. Non Proporsonal

Dua (2) program reasuransi proporsional memiliki peran yang yang besar untuk memperbesar kapasitas penerimaan. Dua (2) program ini terbagi menjadi fakultatif dan treaty, dengan program fakultatif perusahaan dapat menjadi Reasuradur dalam penawaran dari perusahaan asuransi lain sehingga perusahaan ikut memberi sharenya dalam bisnis ceding company sejumlah kemampuan perusahaan. Begitu pula sebaliknya perusahaan dapat menjadi ceding company sehingga dapat menyebarkan kelebihan risiko yang ditanggungnya kepada Reasuradur. Dengan program treaty perusahaan dapat menempatkan risikonya dan secara otomatis besarnya share bagi masing-masing anggota akan terbagi, hal ini dikarenakan dalam reasuransi treaty telah dilakukan perjanjian terlebih dahulu pada awal dimulainya program. Metode treaty ini terbagi menjadi 2 yakni :

\section{Quota Share}

2. Surplus

Jika pada Quota Share besarnya proporsi retensi sendiri ceding company telah ditetapkan sejak awal namun dalam surplus besarnya retensi sendiri ceding company belum ditentukan sehingga ceding company akan lebih mudah memorsikan besarnya retensinya. Dalam menjalankan metoda surplus pun terdapat kekurangan dan 
kelebihannya, diantaranya adalah : Administratif yang rumit dan panjang perusahaan sebagai ceding company harus selalu menyeleksi kembali anggota yang akan mengikuti programnya dan menyiapkan kembali dokumen yang dibutuhkan dalan treaty setiap tahunnya.

\section{PENUTUP}

\section{Simpulan}

Manfaat surplus treaty meningkatnya akseptasi, dengan metode ini perusahaan dapat menentukan besarnya retensi sendiri pada jenis risiko yang sedang ditanggungnya asalkan tidak melebihi limit treaty. Balance of portofolio bisnis sehingga tercapai the law of large number.

\section{Saran}

Kelemahan surplus treaty antara lain sehingga disarankan perusahaan Perusahaan asuransi terkait dapat merealisasikan bisnis yang melebihi O/R kepada Reasuradur (komisi dan cara pembayaran sudah ditetapkan) sehingga bila bisnis sedang baik, perusahaan asuransi harus tetap berbagi keuntungan dengan Reasuradur. Membuat laporan berkala, ceding company harus selalu memberikan laporan untuk bisnis yang berjalan per 3 bulan dalam bentuk nota SOA (Statement of Account) nota ini nantinya akan diberikan kepada anggota treaty sebagai laporan rutin.

\section{DAFTAR PUSTAKA}

Undang - Undang no.2 tahun 1992 mengenai Asuransi

Iskandar, Kasir dkk, Dasar-dasar Asuransi Jiwa Kesehatan, Jiwa dan Anuitas, Asosiasi Ahli Manajemen Asuransi Indonesia, Jakarta, 2011

Goenka, Ashok, Practical Aspects of Reinsurance, Singapoer College of Insurance, 2003.

Strain, Robert W, CLV, CPCV, Reinsurance, The College of Insurance, 1981.

Chief Underwriting Office, An Introduction to Insurance, Swiss Re

htpp://www. tugu.com.

htpp://www. tripakarta.com. 